Jurnal Keuangan dan Perbankan, 21(1): 25-36, 2017
Nationally Accredited: No.040/P/2014
http://jurnal.unmer.ac.id/index.php/jkdp

\title{
CONFIRMATION BIAS, SELF-ATTRIBUTION BIAS, DAN OVERCONFIDENCE DALAM TRANSAKSI SAHAM
}

\author{
Supramono, Marisa Wandita \\ Fakultas Ekonomika dan Bisnis Universitas Kristen Satya Wacana \\ Jl. Diponegoro No.52-60 Salatiga, 50711, Indonesia
}

\begin{abstract}
Keywords:

Overconfidence, Confirmation Bias, Self-Attribution Bias

JEL Classification: G02, G11, G12

Overconfidence caused investors overestimate their knowledge, underestimate risk and exaggerate their ability to control events. This led to excessive trading, unwarranted risk taking, and ultimately, financial losses. The aim of this study was to analyze the relationship of overconfidence and confirmation bias and self-attribution bias. The subjects in this experiment were 53 students in finance classes at Faculty of Economic and Business.Data that had been collected was analyzed using descriptive and inferential analysis techniques using bivariate correlation. The result of this study showed that there was a positive relationship between confirmation bias and overconfidence. However, there was no a positive relationship between self-attribution bias and overconfidence.

Abstrak

Overconfidence menyebabkan investor melebih-lebihkan pengetahuan mereka, meremehkan risiko, dan membesar-besarkan kemampuan mereka untuk mengontrol suatu kejadian. Hal ini menyebabkan trading yang berlebihan, pengambilan risiko yang tidak beralasan, dan akhirnya, kerugian keuangan. Tujuan dari penelitian ini adalah untuk menganalisis hubungan confirmation bias, overconfidence, dan bias self-attribution. Subyek dalam penelitian ini adalah 53 mahasiswa di kelas keuangan di Fakultas Ekonomi dan

Kata Kunci:

Overconfidence, Confirmation Bias, Self-Attribution Bias

Bisnis. Data yang telah dikumpulkan kemudian dianalisis menggunakan teknik analisis deskriptif dan inferensial menggunakan korelasi bivariat. Hasil penelitian ini menunjukkan bahwa ada hubungan positif antara confirmation bias dan overconfidence. Namun, tidak ada hubungan positif antara self-attribution bias dan overconfidence.
\end{abstract}




\section{Jurnal Keuangan dan Perbankan | KEUANGAN}

Vol. 21, No.1, Januari 2017: 25- 36

Perdagangan saham makin populer di masyarakat Indonesia terutama di kalangan mahasiswa. Bahkan muncul galeri-galeri investasi dari berbagai sekuritas di berbagai perguruan tinggi yang mendorong mahasiswa untuk berinvestasi. Saham mulai menjadi pilihan investasi bagi mahasiswa dengan persyaratan yang mudah dan modal yang tidak cukup besar. Menurut data dari BEI, total galeri investasi di perguruan tinggi seluruh Indonesia pada tahun 2015 berjumlah 155 dan ditargetkan pada tahun 2016 mencapai 200 unit (Berita Satu, 2016). Dengan semakin mudahnya melakukan investasi, diharapkan minat investasi saham dikalangan mahasiswa akan meningkat sehingga kelak menambah jumlah investor lokal di Indonesia.

Dalam bertransaksi saham, investor tak terkecuali yang berlatar belakang mahasiswa dituntut untuk memiliki pengetahuan dan pengalaman investasi yang memadai sehingga dapat membuat keputusan yang tepat baik pada saat membeli maupun menjual. Nofsinger (2005) mengingatkan adanya kemungkinan faktor psikologi membuat investor berperilaku tidak rasional yang dapat menyebabkan bias dalam transaksi saham. Salah satu bentuk bias yang dikenal luas dalam keuangan berbasis perilaku (behavioural finance) adalah overconfidence.

Overconfidence merupakan kecenderungan seseorang melakukan penafsiran terlalu tinggi terhadap pengetahuan, kemampuan, dan ketepatan tentang informasi yang mereka miliki (Bhandari \& Deaves, 2006). Fischhoff et al. (1977) menjelaskan ketika seseorang dihadapkan pada ketidakpastian, mereka cenderung mengambil keputusan yang overconfidence. Barber \& Odean (2001), Statman et al. (2003), Biais et al. (2005), dan Doukas \& Petmezas (2007) menyatakan bahwa investor yang overconfidence diketahui memiliki frekuensi trading yang lebih banyak dan memiliki abnormal return yang negatif diantara investor lainnya dikarenakan keoptimisannya dalam bertransaksi sa- ham. Pompian (2006) mengatakan bahwa kesalahan-kesalahan yang biasanya muncul sebagai akibat dari perilaku overconfidence dalam kaitannya dengan investasi di pasar keuangan adalah sebagai berikut: (1) Investor melakukan transaksi yang terlalu berlebihan sebagai efek dari keyakinan bahwa mereka memiliki pengetahuan khusus yang sebenarnya tidak mereka miliki; (2) Overestimate (menaksir terlalu tinggi) terhadap kemampuannya dalam mengevaluasi suatu investasi; (3) Underestimate (menaksir terlalu rendah) terhadap adanya risiko dan cenderung mengabaikan risiko; dan (4) Memiliki kecenderungan tidak mendiversifikasi investasinya. Glaser \& Weber (2003) mengungkapkan bahwa overconfidence terdiri dari 3 aspek yaitu: (1) Miscalibration, yang merupakan kecenderungan seseorang untuk menaksir terlalu tinggi terhadap pengetahuan yang dimiliki; (2) Better than average effect, yaitu kecenderungan seseorang untuk menilai dirinya lebih baik daripada orang lain; dan (3) Illusion of control, yaitu kecenderungan seseorang untuk mempercayai bahwa dirinya memiliki kontrol untuk mempengaruhi hasil suatu keputusan.

Hasil penelitian Park et al. (2000) menunjukkan bahwa perilaku overconfidence berhubungan dengan aspek bias yang lain, yakni confirmation bias yang menunjukkan kecenderungan perilaku investor hanya menerima masukan orang lain yang sesuai dengan pemikirannya, sehingga masukan tersebut digunakan untuk memperkuat pemikirannya. Perilaku ini dapat menyebabkan seseorang menjadi overconfidence. Sementara Hirshleifer (2001) dan Li (2012) mengemukakan bahwa overconfidence juga disebabkan oleh bias lainnya yaitu self-attribution bias. Hasil penelitian Hsu \& Shiu (2007) menjelaskan bahwa investor yang mengalami selfattribution bias akan menganggap keberhasilan yang didapat sebagai kemampuan dan pengetahuan mereka sendiri. Sementara kegagalan dianggap sebagai ketidakberuntungan ataupun sebagai pengaruh faktor eksternal seperti kesalahan penasehat keuangan, mengikuti saran teman, 
ekonomi makro, dan minimnya informasi yang didapat. Perilaku ini akan menyebabkan seorang investor menjadi overconfidence yang dikarenakan seorang investor hanya percaya pada kemampuan dan pengetahuan mereka sendiri yang belum tentu kebenarannya.

Meskipun sudah ada beberapa penelitian overconfidence yang dihubungkan dengan bias lainnya seperti confirmation bias dan self-attribution bias, namun sifatnya masih parsial. Oleh karena itu penelitian ini berusaha mengintegrasikan ketiga jenis bias tersebut. Adapun yang menjadi partisipan penelitian ini adalah mahasiswa Fakultas Ekonomika dan Bisnis sebagai calon investor. Melalui penelitian ini diharapkan mendapatkan gambaran keterkaitan perilaku bias dalam pengambilan keputusan transaksi saham dikalangan mahasiswa.

\section{PENGEMBANGAN HIPOTESIS}

Overconfidence terjadi saat seorang investor overestimate terhadap pengetahuan dan kemampuan yang mengakibatkan kesalahan prediksi (Baker \& Nofsinger, 2002; Ackert \& Deaves, 2010; Tine, 2013). Seorang investor yang mengalami overconfidence akan cenderung mengabaikan informasi yang bermanfaat yang seharusnya dapat meningkatkan tingkat prediksi menjadi lebih baik (Sieck \& Arkes, 2005). Perilaku overconfidence diakibatkan oleh confirmation bias karena investor akan cenderung mengkonfirmasi pandangan yang diyakini daripada mencari informasi yang tidak memperkuat kepercayaannya (Koriat et al., 1980; Nickerson, 1998; Pompian, 2006; Rachel \& Kosnik, 2007; Howard, 2012). Setelah investor menemukan informasi yang sejalan dengan keputusannya, informasi tersebut akan membawa dampak terhadap keoptimisan investor dalam memperoleh keuntungan. Perilaku optimis yang berlebihan ini akan mengarahkan investor keperilaku overconfidence.

Penelitian yang dilakukan oleh Park et al. (2000) terhadap stock message board di Korea Selatan mengemukakan bahwa investor yang memiliki confirmation bias yang kuat akan mengakibatkan seseorang menjadi overconfidence. Karena investor akan mengambil terlalu banyak informasi yang mendukung pandangannya dan mengabaikan informasi yang tidak sesuai dengan pandangannya. Hasil dari penelitian ini menunjukan bahwa confirmation bias akan menyebabkan seorang investor menjadi selektif terhadap informasi yang didapatkan. Informasi yang diterima hanya berdasarkan kepercayaanya sendiri tanpa melihat informasi yang sesungguhnya, sehingga dengan kepercayaannya tersebut seorang investor dapat menjadi overconfidence. Dari kajian konsep dan empiris tersebut, maka ditarik hipotesis 1 sebagai berikut:

$\mathrm{H}_{1}$ : confirmation bias berhubungan positif terhadap perilaku overconfidence dalam transaksi saham

Overconfidence juga disebabkan oleh bias lainnya yaitu self-attribution bias. Investor yang mengalami self-attribution bias cenderung menonjolkan kemampuannya saat mengalami keuntungan dan menghindari tanggung jawab saat mengalami kerugian, karena investor akan mencari pihak untuk bertanggung jawab atas kerugian yang diperolehnya (Miller \& Ross, 1975; Bhandari \& Deaves, 2006). Attribution theory menjelaskan proses kognitif dimana seseorang membuat kesimpulan mengenai penyebab suatu kejadian (Hattu, 2013). Attribution theory memiliki suatu dimensi yang disebut locus of control yang merupakan variabel kepribadian yang diartikan sebagai keyakinan seseorang terhadap kemampuannya dalam mengontrol nasib (Rotter, 1992; Kreitner \& Kinicki, 2001). Terdapat 2 jenis locus of control, yaitu faktor internal dan eksternal. Faktor internal merupakan penjelasan yang menempatkan penyebab internal seseorang mengalami bias yang mencakup kepribadian, mood, kemampuan, sikap, dan upaya. Sedangkan faktor eksternal seperti tugas, orang lain, lingkungan, dan keberuntungan (Turner \& Hewstone, 2012). 


\section{Jurnal Keuangan dan Perbankan | KEUANGAN}

Vol. 21, No.1, Januari 2017: 25- 36

Seseorang yang mengalami self-attribution bias akan cenderung untuk mengunggulkan dirinya sendiri dan berpikir bahwa mereka memiliki kemampuan melebihi orang lain atau yang biasa diketahui sebagai better than average effect (Taylor \& Brown, 1988). Gervais \& Odean (2001) dan Hirschey \& Nofsinger (2008) juga mengungkapkan self-attribution mengakibatkan seseorang menjadi overconfidence saat keputusan investasi yang dibuat menghasilkan keuntungan dikarenakan investor akan beranggapan bahwa dirinya memiliki kemampuan serta pengetahuan yang baik dalam bermain saham, padahal keuntungan tersebut belum tentu berasal dari kemampuan atau pengetahuan yang dimilikinya dan bisa saja disebabkan oleh faktor keberuntungan. Begitupun sebaliknya saat keputusan investasi yang dibuat mengalami kerugian, investor akan menganggap bahwa kerugian tersebut dikarenakan faktor ketidakberuntungan ataupun oleh faktor-faktor di luar kendalinya.

Penelitian yang dilakukan oleh Hsu \& Shiu (2007) memberi bukti empiris bahwa perilaku overconfidence akan bertambah dengan self-attribution bias. Perilaku ini memiliki peranan penting dalam menjelaskan perbedaan performa investasi antara investor yang sering bertransaksi saham dengan yang tidak. Investor yang sering bertransaksi saham memiliki return yang lebih rendah daripada investor yang jarang melakukan transaksi saham. Garveis \& Odean (2001) dan Cremers \& Pareek (2011) menunjukan bahwa self-attribution bias timbul akibat keberhasilan dalam transaksi saham di masa lalu dan menyebabkan investor menjadi overconfidence. Sedangkan disaat seorang investor mengalami kesalahan prediksi yang mengakibatkan kinerjanya memburuk dan mengalami kerugian akan menyebabkan tingkat overconfidence investor menurun. Dari kajian konsep dan empiris tersebut, maka ditarik hipotesis 2 sebagai berikut:

$\mathrm{H}_{2}$ : self-attribution bias berhubungan positif terhadap perilaku overconfidence dalam transaksi saham

\section{METODE}

Penelitian ini menggunakan pendekatan eksperimen. Campbell \& Stanley (1966) menekankan bahwa eksperimen merupakan bagian riset yang memiliki manipulasi atas satu atau lebih variabel independen dan dilakukan pengamatan atas efek variabel tersebut terhadap variabel dependen. Bentuk eksperimen yang dilakukan dalam penelitian ini adalah non-randomisasi, dimana proses seleksi partisipan yang sudah ditentukan sebelumnya dan tidak dilakukan secara acak (Nahartyo, 2013). Adapun partisipan dalam penelitian ini adalah 53 mahasiswa yang mengambil konsentrasi Manajemen Keuangan di Fakultas Ekonomika dan Bisnis, Universitas Kristen Satya Wacana yang didominasi oleh perempuan yakni sebanyak 32 orang $(60,4 \%)$ dan partisipan laki-laki berjumlah 21 orang $(39,6 \%)$.

Seseorang yang memiliki overconfidence akan terlalu percaya diri terhadap kemampuan yang dimilikinya yang belum tentu kebenarannya (Sulphey, 2014). Untuk mendeteksi terjadinya overconfidence, diukur dengan tingkat pengetahuan dan tingkat keyakinan. Variabel overconfidence dalam penelitian ini diklasifikasikan menjadi 2, yakni menggunakan binary dan numerik. Pengklasifikasian pada numerik dilakukan dengan cara skoring atau menjumlahkan total skor jawaban untuk indikator pengetahuan dan overconfidence. Pertanyaan pada variabel overconfidence berjumlah 5 sehingga pengklasifikasian untuk binary dilakukan jika partisipan menjawab 3 buah pernyataan atau lebih dengan jawaban yang salah beserta tingkat keyakinan melebihi 50\%, maka diindikasikan mengalami overconfidence dan diberi nilai 1 begitu juga sebaliknya. Sedangkan pengklasifikasian binary untuk indikator pengetahuan bernilai 1 jika menjawab pertanyaan dengan benar dan diberi nilai 0 jika salah menjawab pertanyaan. Untuk indikator keyakinan diklasifikasikan dari 0-20\%, 21-40\%, 41$60 \%, 61-80 \%$, dan $81-100 \%$ menjadi numerik menggunakan skala interval (1-5). Sedangkan untuk bi- 


\section{Confirmation Bias, Self-attribution Bias, dan Overconfidence dalam Transaksi Saham}

Supramono \& Marisa Wandita

nary pada indikator keyakinan, diklasifikasikan dengan jawaban $51-100 \%$ menandakan yakin yang bernilai 1 dan 0-50\% menandakan tidak yakin dengan nilai 0.

Confirmation bias terjadi saat seorang investor cenderung untuk menafsirkan informasi yang sesuai dengan pemahamannya sebagai bentuk konfirmasi atas pandangannya dan mengabaikan informasi yang bertentangan (Sulphey, 2014). Variabel confirmation bias untuk pengklasifikasian binary diukur dengan pemilihan jawaban berupa "iya", yaitu jawaban yang sejalan dengan keputusan saat bertransaksi saham sejumlah 6 atau lebih. Diberi nilai 1 yang berarti mengalami confirmation bias dan bernilai 0 jika tidak mengalami confirmation bias. Sementara pengklasifikasian numerik dilakukan dengan skoring. Terdapat 2 indikator pada variabel confirmation bias, yakni indikator membeli dan menjual. Indikator ini juga digunakan untuk pengklasifikasian menjadi variabel interval untuk pengujian menggunakan numerik dengan penambahan total skor jawaban.

Investor dikatakan mengalami self-attribution bias jika saat mengalami keuntungan investor akan memilih faktor internal atau faktor yang berasal dari kemampuan dirinya sendiri. Disamping itu juga melihat faktor eksternal atau faktor kerugian yang didapatnya dianggap berasal dari faktor di luar dirinya (Sulphey, 2014). Variabel self-attribution bias terdiri dari 2 indikator yakni faktor internal dan eksternal. Masing-masing faktor internal dan eksternal diukur dengan menggunakan skala interval 1-5, dimana apabila semakin mendekati 5 maka responden akan semakin setuju dan begitu juga sebaliknya.

Instrumen eksperimen terdiri dari 3 variabel yakni overconfidence, confirmation bias, dan self-attribution bias. Pola pertanyaan overconfidence dan confirmation bias diadopsi dari Pompian (2006) sedangkan pola pertanyaan self-attribution bias diadopsi dari Zuckerman (1979). Adapun pertanyaan yang digunakan untuk mengukur tingkat overconfidence berbentuk pernyataan mengenai kode saham dari perusahaan Gudang Garam Tbk, perusahaan dengan kode saham SMCB, terbentuknya Bursa Efek Indonesia (BEI), perusahaan BUMN di BEI, dan perusahaan go public di BEI. Dalam pernyataan tersebut terdapat jawaban yang benar dan salah. Kebenaran jawaban pada pernyataan overconfidence yakni: (1) GGRM; (2) Holcim Indonesia Tbk; (3) 2007; (4) 17; dan (5) 517. Pertanyaan mengenai confirmation bias berjumlah 10 buah yang berisi 5 buah pertanyaan yang terdiri dari keputusan menjual dan membeli yang meliputi pencarian informasi yang hanya mendukung keputusan, memperhatikan pendapat yang sesuai dengan keputusan, menggunakan informasi yang sejalan sebagai bahan pertimbangan, mengutamakan informasi yang sesuai dengan pemahaman sendiri, dan tetap memilih keputusan sebelumnya meskipun terdapat informasi yang bertentangan. Sedangkan untuk variabel self-attribution bias terdapat 8 buah pertanyaan yang terdiri dari 4 buah pertanyaan mengenai faktor internal yang meliputi keuntungan dalam bertransaksi saham dikarenakan pengetahuan, kemampuan analisis, kepandaian, dan pemahaman yang dimiliki seseorang. Sedangkan untuk 4 buah pertanyaan mengenai faktor eksternal, yakni kerugian dalam bertransaksi saham adalah karena keterbatasan informasi, ketidakberuntungan, adanya berita buruk dari perusahaan, dan kondisi pasar yang sulit diprediksi.

Proses eksperimen dilakukan dengan membagikan instrumen penelitian kepada mahasiswa yang mengambil mata kuliah personal finance yang dilakukan di dalam kelas dengan memberikan waktu 30 menit bagi partisipan untuk mengisinya. Sebelum melakukan eksperimen, peneliti menjelaskan petunjuk pengisian. Eksperimen terbagi dalam 2 sesi. Pada sesi pertama yakni pada tanggal 26 November 2015, partisipan diminta menempatkan diri seolah-olah menjadi seorang investor. Pada 


\section{Jurnal Keuangan dan Perbankan | KEUANGAN}

Vol. 21, No.1, Januari 2017: 25- 36

sesi ini partisipan diminta mengisi instrumen berkaitan variabel overconfidence dan confirmation bias. Selain itu juga diberikan informasi mengenai profil 5 jenis saham perusahaan tertentu dan kemudian partisipan diminta untuk melakukan keputusan transaksi, menjual atau membeli untuk seminggu ke depan dalam mengukur self-attribution bias.

Pada sesi kedua yakni pada tanggal 3 Desember 2015, khusus untuk mengukur variabel self-attribution bias, dimana partisipan diminta untuk mengisi pertanyaan dengan memilih jawaban yang dianggap paling benar berdasarkan keputusan dalam bertransaksi saham seminggu yang lalu. Pada penelitian ini nama perusahaan yang digunakan tidak menggunakan nama yang sesungguhnya agar dapat memperoleh hasil yang lebih objektif. Instrumen penelitian dibuat dengan memanipulasi kondisi dunia nyata ke dalam tatanan eksperimen sehingga partisipan diminta untuk berimajinasi layaknya mereka sedang melakukan trading saham, dan pada tahap terakhir peneliti akan mengecek kelengkapan instrumen penelitian yang telah diisi oleh partisipan.

Teknik analisis dalam penelitian ini menggunakan statistik deskriptif berupa mean, modus, dan standar deviasi yang digunakan untuk memaparkan profil responden dan indikator variabel. Pengujian ini menggunakan korelasi spearman untuk menguji hubungan masing-masing variabel yakni confirmation bias dan self-attribution bias terhadap perilaku overconfidence dalam transaksi saham. Dalam rangka memperoleh hasil pengujian yang lebih bisa dipertanggungjawabkan (robust), dilakukan model pengujian dengan model lain bukan hanya binary melainkan numerik dan $\log$ numerik.

Sebelum melakukan analisis korelasi bivariate, dilakukan uji validitas dan uji reliabilitias untuk menguji kehandalan atau kevalidan yang digunakan dalam penelitian. Hasil pengujian validitas selfattribution bias berkisar 0,284-0,668. Keseluruhan hasil pengujian tersebut melebihi nilai $r$ tabel se- hingga instrumen self-attribution bias dikatakan valid. Sementara untuk uji reliabilitas dalam penelitian ini menggunakan alpha crobanch. Suatu instrumen dikatakan reliabel jika nilai koefisien melebihi 0,6. Dari hasil uji reliabilitas didapat nilai 0,799 yang menunjukkan hasil instrumen penelitian selfattribution bias reliabel dan memenuhi persyaratan untuk digunakan pada analisis selanjutnya.

\section{HASIL}

\section{Statistik Deskriptif}

Tabel 1 menunjukkan statistik deskriptif mengenai sejauh mana partisipan mengalami overconfidence, confirmation bias, dan self-atribution bias dalam keputusan transaksi saham. Secara keseluruhan rata-rata presentase jumlah partisipan yang menjawab salah dengan tingkat keyakinan tinggi yaitu mencapai $61,5 \%$. Item yang tinggi ditemukan pada 3 buah pertanyaan yang memiliki presentase berturut-turut sebesar $77,4 \%, 73,6 \%$, dan $62,3 \%$. Rata-rata indikator pengetahuan secara keseluruhan adalah hanya 36,2\% dengan kebenaran jawaban tertinggi sebesar $50,9 \%$ yang terletak pada pertanyaan ketiga mengenai terbentuknya BEI dan rata-rata keyakinan sebesar $70,48 \%$. Keseluruhan pertanyaan memiliki tingkat keyakinan yang tinggi dengan tingkat keyakinan terbesar adalah $80,75 \%$ pada pertanyaan pertama mengenai kode saham. Hasil tersebut memberikan bukti empiris bahwa partisipan memiliki pengetahuan yang minim tentang saham namun memiliki tingkat keyakinan yang tinggi atas kebenaran jawaban yang diberikannya sehingga mengakibatkan partisipan mengalami overconfidence yang tinggi.

Untuk variabel confirmation bias secara keseluruhan memiliki rata-rata $71,3 \%$. Variabel dibagi menjadi 2 kategori yaitu dalam kondisi transaksi beli dan transaksi jual. Rata-rata pada saat transaksi atau keputusan membeli sebesar 70,9\% dan kepu- 
tusan menjual sebesar 71,7\%. Hasil tersebut dapat dimaknai bahwa partisipan cenderung mengalami confirmation bias. Sedangkan untuk variabel self-attribution bias, secara keseluruhan rata-rata skornya adalah 3,56 dengan standar deviasi sebesar 0,753. Untuk internal self-attribution bias dan eksternal selfattribution bias rata-rata skornya masing adalah 3,65 dan 3,47. Dengan demikian partisipan cenderung mengalami self-attribution bias tinggi karena lebih beranggapan bahwa keuntungan yang diperoleh berasal dari kemampuannya daripada sekedar faktor eksternal.

\section{Hasil Uji Hipotesis}

Untuk menguji hipotesis, dilakukan analisis korelasi bivariate (product moment dan spearman) yang melibatkan 3 model persamaan. Berdasarkan Tabel 2 diketahui bahwa secara keseluruhan koefisien korelasi confirmation bias untuk model numerik $(0,242)$, model $\log$ numerik $(0,294)$, dan model binari $(0,402)$. Semuanya signifikan pada $\alpha$ $<0,05$ dan 0,01 . Dengan demikian, dapat disimpulkan bahwa $\mathrm{H}_{1}$ terbukti (diterima).

Hal ini berarti confirmation bias memiliki hubungan positif terhadap perilaku overconfidence dalam transaksi saham. Lebih lanjut diketahui bahwa koefisien korelasi pada confirmation bias baik saat keputusan membeli dan menjual juga positif dan signifikan sehingga dapat dimaknai bahwa hubungan confirmation bias dengan overconfidence terjadi baik saat transaksi beli maupun jual.

Sementara itu, hasil pengujian hipotesis kedua $\left(\mathrm{H}_{2}\right)$ sebagaimana ditunjukkan pada Tabel 2, bahwa secara keseluruhan koefisen korelasi selfattribution bias untuk model numerik $(-0,018)$, model $\log$ numerik $(0,054)$, dan model binari $(0,080)$. Namun tidak ada satupun yang signifikan, dengan demikian dapat disimpulkan bahwa $\mathrm{H}_{2}$ tidak terbukti (ditolak).
Hal ini berarti tidak terdapat hubungan yang positif antara self-attribution bias dan overconfidence. Hasil tersebut juga diperkuat hasil pengujian terhadap kategori internal self-atribution bias dan eksternal selfatribution bias yang menunjukan tidak ada yang signifikan.

\section{PEMBAHASAN}

Hasil penelitian menunjukkan hasil yang positif dan signifikan antar variabel confirmation bias terhadap overconfidence. Investor yang mengalami confirmation bias hanya mau mencari dan menerima informasi yang sesuai dengan pemikirannya. Sedangkan informasi yang bertentangan dengan keputusannya akan diabaikan. Informasi tersebut membuat keoptimisan investor meningkat dan menjadikan seorang investor mengalami overconfidence. Dengan kata lain, investor yang mengalami confirmation bias hanya mau mendengar apa yang mereka mau dengar yang akhirnya mengarah pada perilaku overconfidence. Perilaku ini tidak menutup kemungkinan investor akan sering mengalami kerugian dalam bertransaksi. Temuan ini sejalan dengan hasil penelitian Park et al. (2000) yang menunjukkan bahwa confirmation bias akan menyebabkan tingkat overconfidence investor bertambah. Hasil penelitian juga menemukan bahwa partisipan mengalami confirmation bias baik saat melakukan transaksi jual maupun beli. Hal ini membawa implikasi bahwa saat investor mau melakukan transaksi beli, investor hanya berusaha mencari informasi yang positif (good news). Sedangkan saat mau melakukan transaksi jual, hanya berusaha mencari informasi yang negatif tentang saham yang bersangkutan (bad news). Padahal seorang investor selain dituntut untuk cepat membuat keputusan, yang tidak kalah penting harus objektif sehingga mau mendengar pendapat atau informasi yang bertentangan dengan pemikirannya (Pompian, 2006). 


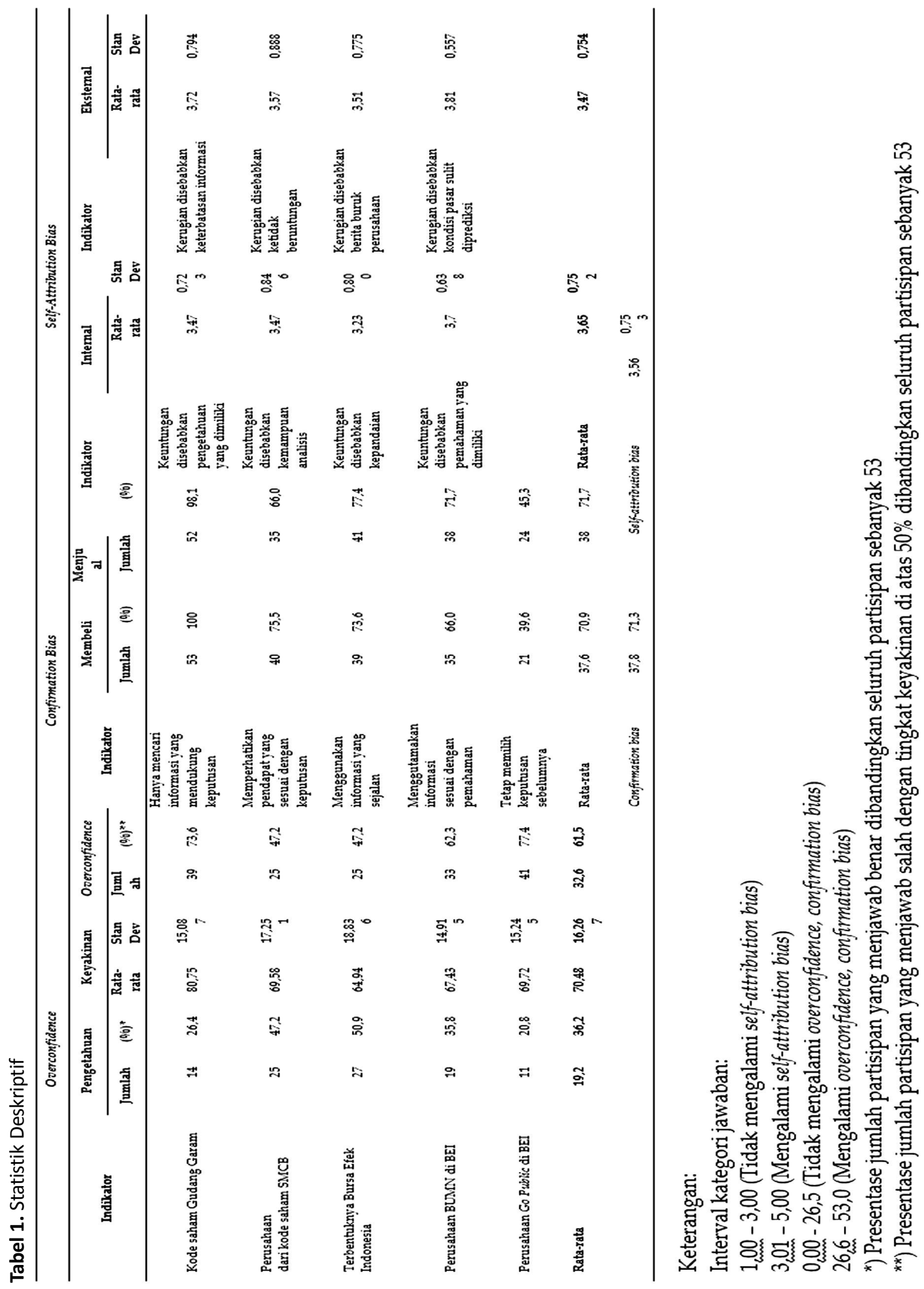




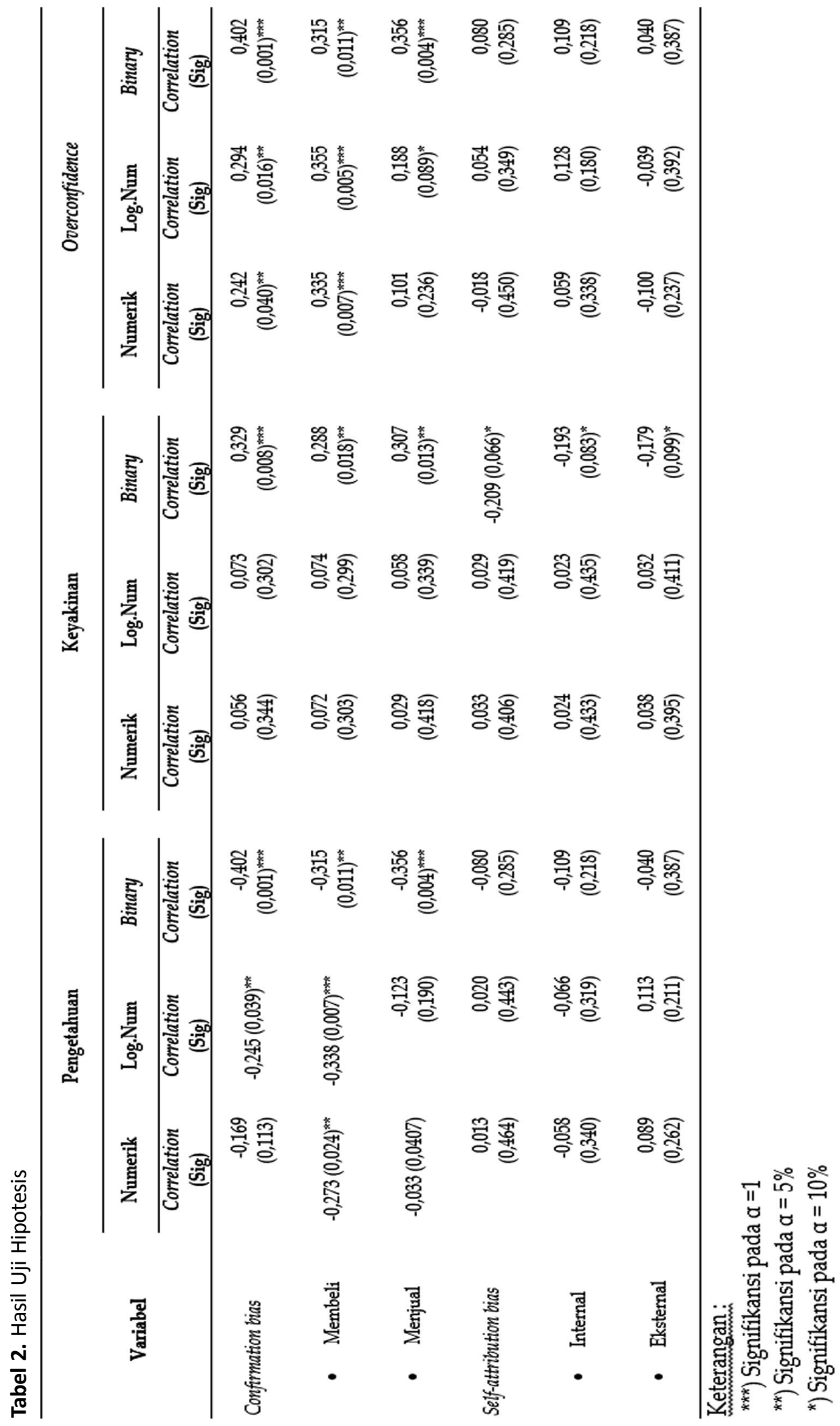


Hasil penelitian antara kaitan self-attribution bias terhadap overconfidence tidak menunjukkan hubungan yang positif dan signifikan. Hasil penelitian ini kontradiksi dengan penelitian sebelumnya yang dilakukan oleh Gervais \& Odean (2001), Hsu \& Shiu (2007), serta Hoffman \& Post (2013) yang menemukan bahwa self-attribution bias memiliki korelasi positif dengan perilaku overconfidence. Perilaku self-attribution bias tidak secara langsung berhubungan dengan overconfidence diduga ada variabel lain (intervening), dalam hal ini adalah illusion of control yang merupakan sumber dari overconfidence (Nofsinger, 2005). Sepanjang self-attribution bias tidak menimbulkan anggapan investor untuk menguasai kontrol atas keuntungan dan kerugian yang diperoleh (illusion of control), maka tidak menjadikan dirinya overconfidence. Hal ini dapat dimaknai jika investor beranggapan bahwa memperoleh keuntungan transaksi saham tidak hanya dikaitkan dengan kemampuan investor yang bersangkutan dan sebaliknya investor tidak hanya beranggapan bahwa kerugian diakibatkan kondisi eksternal, maka tidak akan menyebabkan terjadinya overconfidence.

\section{SIMPULAN DAN SARAN}

\section{Simpulan}

Penelitian ini bertujuan untuk menganalisis hubungan confirmation bias, overconfidence, dan bias self-attribution. Hasil analisis menunjukkan bahwa sebagian besar partisipan cenderung mengalami overconfidence karena dengan pengetahuan yang masih relatif rendah, tetapi memiliki tingkat keyakinan tinggi bahwa yang bersangkutan mampu menjawab sesuatu dengan benar. Partisipan juga mengalami confirmation bias dan self-attribution bias yang tinggi. Confirmation bias memiliki hubungan positif terhadap overconfidence yang berarti semakin tinggi tingkat confirmation bias, maka semakin tinggi pula tingkat overconfidence yang akan dialami dan demikian juga sebaliknya. Namun ada temuan yang menarik dan masih menimbulkan tanda tanya adalah self-attribution bias tidak memiliki hubungan yang positif dengan overconfidence.

Dari hasil penelitian yang didapatkan yaitu confirmation bias berhubungan dengan perilaku overconfidence, maka para investor diharapkan dapat mengurangi perilaku confirmation bias dalam transaksi saham baik dalam aksi beli dan jual dengan menjadi pribadi yang lebih objektif dan mau mendengar pendapat orang lain yang memiliki pendapat yang berbeda.

\section{Saran}

Setiap penelitian tidak terlepas dari adanya keterbatasan, demikian juga dengan penelitian ini. Di sisi lain, keterbatasan akan membuka peluang terjadinya agenda penelitian di masa datang. Keterbatasan penelitian ini meliputi: (1) Penelitian ini masih sebatas menggunakan mahasiswa sebagai calon investor, sehingga ada kemungkinan bias dan belum bisa dilakukan generalisasi kepada investor, objek yang digunakan dalam eksperimen ini juga relatif homogen, sehingga untuk penelitian mendatang disarankan untuk menggunakan objek mahasiswa yang sudah melakukan trading saham di pasar modal sebagai investor dan tidak hanya melibatkan partisipan dari kalangan mahasiswa S1 saja, tetapi juga mahasiswa S2 dan S3 yang memiliki tingkat pengetahuan yang lebih tinggi agar diperoleh hasil yang lebih representatif mengingat tingkat pendidikan memiliki probabilitas yang tinggi berhubungan dengan perilaku bias; (2) Pelaksanaan eksperimen dilakukan bersamaan dengan perkuliahan sehingga tingkat ketelitian mahasiswa dan fokus untuk memberikan penelitian berkurang. Juga dimungkinkan karena waktu yang bersamaan dan posisi duduk yang berdekatan mahasiswa dapat mengikuti jawaban mahasiswa lain, hal ini dapat berdampak pada hasil yang bias. Maka pada penelitian mendatang dapat mencari waktu khusus untuk melakukan eksperimen agar mem- 
peroleh hasil eksperimen yang lebih baik; (3) Penggunaan instrumen self-attribution bias tidak secara spesifik mengungkapkan faktor keberuntungan, investor yang menyatakan bahwa keuntungan yang diperolehnya bukan berasal dari faktor keberuntungan tetapi kemampuan yang bersangkutan dalam bertransaksi, maka investor tersebut cenderung mengalami self-attribution bias sehingga untuk penelitian yang akan datang diharapkan dapat menggungkapkan secara spesifik mengenai faktor keberuntungan.

\section{DAFTAR PUSTAKA}

Ackert, L.F. \& Deaves, R. 2010. Behavioral Finance: Psychology, Decision-making, and Markets. Ohio: South-Western Cengage Learning.

Barber, B.M. \& Odean, T. 2001. Boys Will be Boys: Gender, Overconfidence, and Common Stock Investment. The Quarterly Journal of Economics, 261-292.

Baker, K.H. \& Nofsinger, J.R. 2002. Psychology Biases of Investors. Finansial Services Review, 11(2): 97-116.

Berita Satu. 2016. Pacu Sosialisasi Pasar Modal, BEI akan Tambah 45 Gallery Investasi. http:/ / beritasatu.com/ pasar-modal/337377-pacu-sosialisasi-pasarmodal-bei-akan-tambah-45-gallery-investasi.html. Diakses tanggal 19 Febuari 2016.

Biais, B., Hilton, D., Mazurier, K., \& Pouget, S. 2005. Judgemental Overconfidence, Self-Monitoring and Trading Performance in an Experimental Financial Market. The Review of Economic Studies, 72(2): 287312.

Bhandari, G. \& Deaves, R. 2006. The Demographics of Overconfidence. The Journal of Behavioral Finance, 7(1): 5-11.

Campbell, D.T. \& Stanley, J.C. 1966. Experimental and Quasi-Experimental Design for Research. Boston: Houghton Mifflin Company.

Cremers, M. \& Pareek, A. 2011. Can Overconfidence and Biased Self-Attribution Explain The Momentun, Reversal and Shares Issuance Anomalies? Evidence From Short-Term Institutional Investors. SSRN Electronic Journal.
Doukas, J.A. \& Petmezas, D. 2007. Acquisition, Overconfident Managers, and Self-Attribution Bias. European Financial Management 13(3): 531-577.

Garveis, S. \& Odean, T. 2001. Learning to be Overconfident. The Review of Financial Studies, 14(1): 1-27.

Glaser, M. \& Weber, M. 2003. Momentum and Turnover: Evidence from the German Stock Market. Schmalenbach Business Review, 55(2): 108-135.

Hirschey, M. \& Nofsinger, J. 2008. Investments: Analysis and Behavior. New York: McGraw-Hill.

Hirshleifer, D. 2001. Investor Psychology and Asset Pricing. The Journal of The American Finance Association, 56(4): 1533-1597.

Hoffman, A.O.I. \& Post, T. 2013. Self-Attribution Bias in Consumer Financial Decision-Making: How Investment Returns Affect Individuals'Belief in Skill. Journal of Behavioral and Eksperimental Economics, 52: 23-28.

Howard, J.A. 2012. Behavioral Finance: Contributions of Cognitive Psychology and Neuroscience to Desicion Making. Journal of Organizational Psychology, 12(2): 52-70.

Hsu, Y. \& Shiu, C.Y. 2007. The Overconfidence and SelfAttribution Bias of Investors in the Primary Market. Pacific-Basin Finance Journal, 18(2): 217-239.

Koriat, A., Lichtenstein, S., \& Fischhoff, B. 1980. Reasons for Confidence. Journal of Experimental Psychology: Human Learning and Memory, 6(2): 107-118.

Kreitner, R. \& Kinicki, A. 2001. Fundamental of Organizational Behaviour. Fifth Edition. New York: McGraw-Hill.

Fischhoff, B., Slovic, P., \& Lichtenstein, S. 1977. Knowing with Certainty: The Apporpriateness of Extreme Confidence. Journal of Experimental Psychology: Human Perception and Performance, 3(4): 552-564.

Li, F. 2012. Managers Self-Serving Attribution Bias and Corporate Financial Policies. Advanced Institute of Finance Shanghai Jiaotong University.

Miller, D.T. \& Ross, M. 1975. Self-Serving Biases in the Attribution of Casuality: Fact or Fiction? Psychological Bulletin, 82(2): 213-225. 


\section{Jurnal Keuangan dan Perbankan | KEUANGAN}

Vol. 21, No.1, Januari 2017: 25- 36

Nahartyo, E. 2013. Desain dan Implementasi Riset Eksperimen. Edisi Kedua. Yogyakarta: UPP STIM YKPN.

Nickerson, R.S. 1998. Confirmation Bias: A Ubiquitous Phenomenon in Many Guises. Review of General Psychology, 2(2): 175-220.

Nofsinger, J.R. 2005. The Psychology of Investing. Second Edition. New Jersey: Pearson Education.

Park, J., Konana, P., Gu, B., Kumar, A., \& Raghunathan, R. 2010. Confirmation Bias, Overconfidence, and Investment Performance: Evidence from Stock Market Boards. McCombs Research Paper Series, 710.

Pompian, M.M. 2006. Behavioral Finance \& Wealth Management: How to Build Optimal Portofolios That Account for Investor Biases. New Jersey: John Wiley \& Sons Inc.

Pompian, M.M. 2012. Behavior Finance and Investor Types Managing Behavior to Make Better Investment Decisions. New Jersey: John Wiley \& Sons Inc.

Kosnik, L.R.D. 2007. Refusing to Budge: A Confirmatory Bias in Decision Making? Mind E Society, 7(2): 193214.

Rotter, J.B. 1992. Cognates of Personal Control: Locus of Control, Self-Efficacy, and Explanatory Style. Applied and Preventive Psyychology, 1(2): 111-117.
Sieck, W.R. \& Arkes, H.R. 2005. The Recalcitrance of Overconfidence and Its Contribution to Decision Aid Neglect. Journal of Behavioral Decision Making, 18(1): 29-53.

Sulphey, M.M. 2014. Behavioural Finance. Delhi: PHI Learning Private Limited.

Hattu, E.M. 2013. Self-Attribution Bias dan Faktor Demografi dalam Pengambilan Keputusan Trading Valuta Asing. Thesis. Fakultas Ekonomi dan Bisnis Universitas Kristen Satya Wacana.

Statman, M., Thorley, S., \& Vorkink K. 2003. Investor Overconfidence and Trading Volume. The Review of Financial Studies, 19(4): 1531-1565.

Taylor, S.E. \& Brown, J.D. Illusion and Well-Being: A Social Psychological Perspective on Mental Health. Psychological Bulletin, 103(2): 193-210.

Tine, D.C. 2013. Attribution Bias and Overconfidence in Escalation of Commitment: The Role of Desire to Rectify Past Outcomes. Scholar Works Georgia State University.

Turner, R.N. \& Hewstone, M. 2012. Attribution Biases. Encyclopedia of Group Processes \& Intergroup Relations Sage Publication, 43-46.

Zuckerman, M. 1979. Attributions of Success and Failure Revisited, or The Motivational Bias is Alive and Well in Attribution Theory. Journal of Personality, 47(2): 245-287. 